Brit. Heart f., 1967, 29, 411.

\title{
Peripheral Pulmonary Artery Murmur of Atrial Septal Defect ${ }^{\star}$
}

\author{
JOSEPH K. PERLOFF, WALTER H. CAULFIELD, AND ANTONIO C. DE LEON
}

\author{
From the Department of Medicine, Georgetown University School of Medicine, Division of Cardiology, Georgetown \\ University Hospital, Washington, D.C.
}

Extracardiac murmurs originating in vessels either within the thoracic cavity or in the chest wall can be sought by applying clinical auscultation to non-præcordial sites, i.e. right anterior chest, axillæ, and back. Recognized causes of such murmurs include branch stenosis of the pulmonary arteries (D'Cruz et al., 1964), coarctation of the aorta (Spencer, Johnston, and Meredith, 1958), bronchial collateral circulation (Campbell and Deuchar, 1961), arteriovenous fistulæ of the chest wall (Levine and Harvey, 1959), pulmonary arteriovenous fistulæ (Sloan and Cooley, 1953), the mammary souffle (Grant, 1956), and pulmonary emboli (Moser et al., 1965). Current interest in the clinical recognition of pulmonary artery stenosis has served to re-emphasize the utility of non-præcordial thoracic auscultation. Diagnostic inferences drawn from the detection of these murmurs benefit from knowledge of their many causes. Accordingly, this study was undertaken in order to call attention to a hitherto unrecognized intrathoracic vascular murmur-the peripheral pulmonary artery murmur of atrial septal defect.

\section{Material AND Methods}

Observations were made on seven patients (Table I). Clinical diagnoses of atrial septal defect (Cases 1-6) were based upon typical physical signs, electrocardiograms, and chest $x$-ray films, but in each instance detection of "peripheral pulmonary artery murmurs" resulted in consideration of coexisting pulmonary branch stenosis. In one patient, a 10-year-old boy, maternal exposure to rubella enhanced this consideration (Venables, 1965). Phonocardiograms were taken with a Sanborn polybeam

Received March 29, 1966.

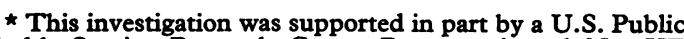
Health Service Research Career Program Award No. HE 14-009 and by a U.S. Public Health Service Grant No. 3319 from the National Heart Institute, Bethesda, Md, U.S.A. photographic recorder after careful auscultation. The tracings permitted comparisons of the relative amplitudes of systolic murmurs in any given patient (Table I, Fig. 1 and 2). In order to validate such comparisons, use was made of either a single microphone or of paired microphones calibrated to respond identically in both frequency and intensity. Graphic records were taken at the cardiac apex, lower left sternal edge, second interspaces to left and right of the sternum, and at appropriate murmur sites in the right anterior chest, axillæ, and back (Fig. 1 and 2). Pre- and post-operative phonocardiograms were obtained in the two surgical patients (operated upon by Dr Charles A. Hufnagel). Diagnoses of atrial septal defects (Case 5, ostium primum) were confirmed by cardiac catheterization in six patients (Table II) and at open operation in two (one of whom was catheterized elsewhere). In the five subjects studied in our laboratory, coexisting pulmonary branch stenosis was deliberately sought by, (1) careful continuous withdrawal of the catheter tip from the peripheral branches of both right and left pulmonary arteries into the right ventricle, (2) inspection of the contour of the pressure pulse recorded from the main pulmonary artery (Agustsson et al., 1962), and (3) selective pulmonary angiocardiography (Arvidsson, Karnell, and Möller, 1955). The catheter crossed an atrial septal defect in each of the five patients. Localization of the shunt was confirmed by appropriate intracardiac injection of indocyanine green dye. Determinations of the grade of the shunts were based upon the radioactivity in pulmonary and systemic arterial blood following inhalation of krypton 85. Pulmonary circulation times were estimated by comparing the systemic appearance times of indicator injected into the main pulmonary artery and left atrium.

In addition to the foregoing six subjects, one further patient (Case 7)-a 6-year-old boy with ventricular septal defect-was included to permit points of comparison with Cases 1-6. This boy had clinical signs of ventricular septal defect with pulmonary hypertension and persistent left-to-right shunt. Coexisting pulmonary branch stenosis was considered because of high frequency continuous murmurs most evident in the right anterior chest and in both axillæ (Table I, Fig. 3). The 
TABLE

CLINICAL AND PHONO

\begin{tabular}{|c|c|c|c|c|c|c|c|c|}
\hline \multirow[t]{2}{*}{ Patient } & \multirow{2}{*}{$\begin{array}{l}\text { Age } \\
\text { (yr.) }\end{array}$} & \multirow[t]{2}{*}{ Sex } & \multirow[t]{2}{*}{ Cardiac symptoms } & \multirow{2}{*}{$\begin{array}{l}\text { Right } \\
\text { ventricular } \\
\text { impulse }\end{array}$} & \multirow{2}{*}{$\begin{array}{c}\text { Præcordial } \\
\text { murmur }\end{array}$} & \multicolumn{3}{|c|}{ Peripheral pulmonary murmur } \\
\hline & & & & & & $\begin{array}{l}\text { Right } \\
\text { chest }\end{array}$ & Axillæx & Back \\
\hline $\begin{array}{l}1 \\
2 \\
3\end{array}$ & $\begin{array}{r}10 \\
21 \\
3\end{array}$ & $\begin{array}{l}\mathbf{F} \\
\mathbf{M} \\
\mathbf{M}\end{array}$ & $\begin{array}{l}\text { Nil } \\
\text { Effort dyspncea, fatigue } \\
\text { Nil }\end{array}$ & $\begin{array}{l}\text { Obvious } \\
\text { Obvious } \\
\text { Obvious }\end{array}$ & $\begin{array}{r}3 / 6 \\
3 / 6 \\
2-3 / 6\end{array}$ & $\begin{array}{l}2 / 6 \\
3 / 6 \\
-\end{array}$ & $\begin{array}{l}\text { Both } \overline{3 / 6} \\
\text { Both 2-3/6 }\end{array}$ & $\begin{array}{l}\text { Lung bases } 3 / 6 \\
\text { Widespread } 3 / 6 \\
\text { At angles of }\end{array}$ \\
\hline $\begin{array}{l}4 \\
5 \\
6\end{array}$ & $\begin{array}{c}4 \cdot 5 \\
3 \cdot 5 \\
10\end{array}$ & $\begin{array}{l}\mathbf{M} \\
\mathbf{M}\end{array}$ & $\begin{array}{l}\text { Nil } \\
\text { Nil } \\
\text { Nil }\end{array}$ & $\begin{array}{l}\text { Obvious } \\
\text { Moderate } \\
\text { Obvious }\end{array}$ & $\begin{array}{l}3 / 6 \\
3 / 6 \\
2 / 6\end{array}$ & $\underline{2-3 / 6}$ & $\begin{array}{l}\text { Both } 3 / 6 \\
\text { Both 2/6 } \\
\text { Both } 2 / 6\end{array}$ & $\begin{array}{l}\text { Lung bases } 3 / 6 \\
\text { Lung bases } 2 / 6 \\
\text { At angles of }\end{array}$ \\
\hline $7^{\star}$ & 6 & $\mathbf{M}$ & Mild effort dyspnoea & Obvious & $4 / 6$ & $2 / 6$ & & Nil \\
\hline
\end{tabular}

$\star$ Ventricular septal defect.

final diagnosis of isolated pulmonary hypertensive ventricular septal defect was based upon cardiac catheterization, selective pulmonary angiocardiography, and upon operation (Dr Charles A. Hufnagel).

\section{RESULTS}

Clinical and phonocardiographic information is summarized in Table I. Attention is called to the disappearance of the "peripheral pulmonary artery" murmurs in the three patients who were operated on. The physiological information is summarized in Table II. Coexisting pulmonary branch steno- sis could not be confirmed in any of the cases by either hæmodynamic or angiocardiographic data.

\section{Discussion}

Systolic murmurs associated with uncomplicated atrial septal defect were mentioned in early accounts of this malformation (Bedford, Papp, and Parkinson, 1941). Origin of the murmur at the pulmonary orifice and not at the septal defect was shown experimentally by Rushmer (1961) and confirmed with intracardiac phonocardiography by Soulié et al.

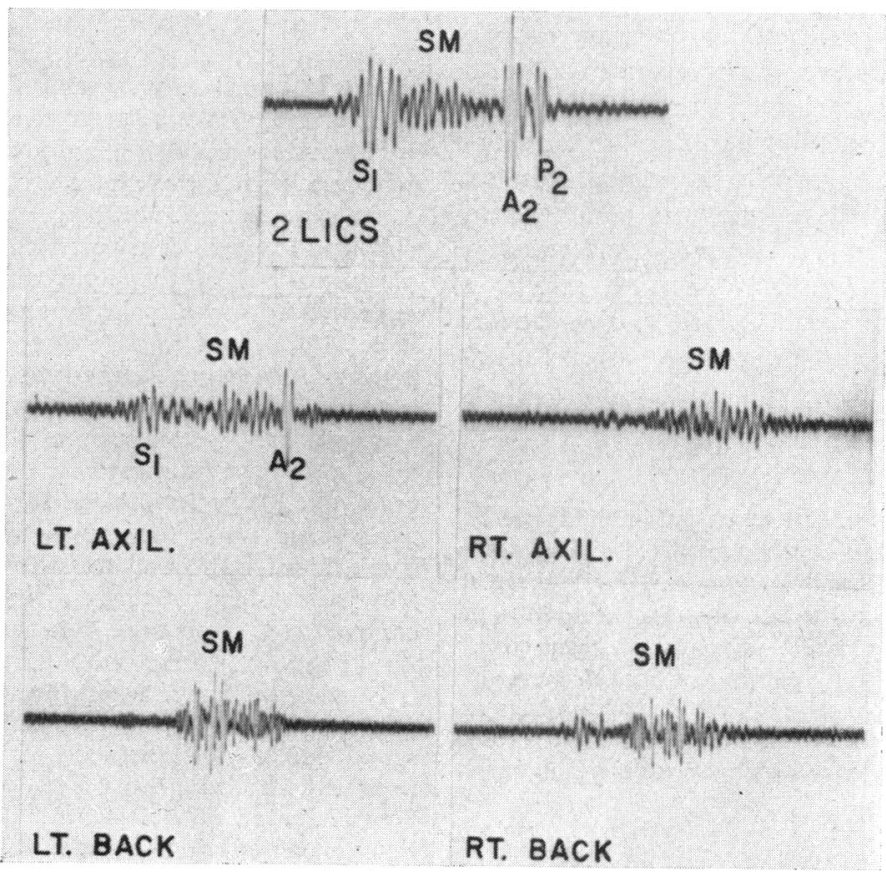

FIG. 1.-Phonocardiograms taken in the second left intercostal space (2LICS) and at four non-præcordial sites (Case 2). $\mathbf{S}_{1}$-first heart sound. $\mathbf{A}_{2}$-aortic valve closure. $\mathbf{P}_{2}$-pulmonary valve closure. SMejection systolic murmur. 
I CARDIOGRAPHIC DATA

\begin{tabular}{|c|c|c|c|c|c|c|c|}
\hline \multirow{2}{*}{$\begin{array}{l}\text { Mitral } \\
\text { diastolic } \\
\text { murmur }\end{array}$} & \multicolumn{2}{|c|}{$\mathbf{S}_{\mathbf{2}}$} & \multicolumn{2}{|c|}{ Electrocardiogram } & \multicolumn{3}{|c|}{$X$-ray films } \\
\hline & Split & $\mathbf{P}_{\mathbf{2}}$ & Axis & $\mathrm{V}_{1}$ & Plethora & $\underset{\text { ventricle }}{\text { Right }}$ & $\begin{array}{l}\text { Dilatation } \\
\text { of pulmonary } \\
\text { artery }\end{array}$ \\
\hline $\begin{array}{l} \pm \\
\pm \\
\pm\end{array}$ & $\begin{array}{l}\text { Fixed } \\
\text { Fixed } \\
\text { Fixed }\end{array}$ & $\begin{array}{l}\text { Normal } \\
\text { Normal } \\
\text { Moderate } \\
\text { increase }\end{array}$ & $\begin{array}{l}\text { Right axis deviation } \\
\text { Right axis deviation } \\
\text { Right axis deviation }\end{array}$ & $\begin{array}{l}8 \mathrm{~mm} . \mathbf{R}^{\prime} \\
9 \mathrm{~mm} . \mathbf{R}^{\prime} \\
11 \mathrm{~mm} . \mathbf{R}^{\prime}\end{array}$ & $\begin{array}{l}\text { Marked } \\
\text { Marked } \\
\text { Marked }\end{array}$ & $\begin{array}{l}\text { Moderate } \\
\text { Marked } \\
\text { Moderate }\end{array}$ & $\begin{array}{l}\text { Moderate } \\
\text { Marked } \\
\text { Marked }\end{array}$ \\
\hline $\begin{array}{l} \pm \\
1 / 6 \\
2 / 6\end{array}$ & $\begin{array}{l}\text { Fixed } \\
\text { Fixed } \\
\text { Fixed }\end{array}$ & $\begin{array}{l}\text { Normal } \\
\text { Normal } \\
\text { Normal }\end{array}$ & $\begin{array}{l}\text { Vertical } \\
\text { Left axis deviation } \\
\text { Vertical }\end{array}$ & $\begin{array}{l}14 \mathrm{~mm} . \mathbf{R}^{\prime} \\
4 \mathrm{~mm} . \mathbf{R}^{\prime} \\
13 \mathrm{~mm} . \mathbf{R}^{\prime}\end{array}$ & $\begin{array}{l}\text { Marked } \\
\text { Marked } \\
\text { Marked }\end{array}$ & $\begin{array}{l}\text { Moderate } \\
\text { Moderate } \\
\text { Moderate }\end{array}$ & $\begin{array}{l}\text { Moderate } \\
\text { Moderate } \\
\text { Moderate }\end{array}$ \\
\hline Nil & Normal & Increase & Right axis deviation & $10 \mathrm{~mm} \cdot \mathrm{R}^{\prime}$ & Moderate & Moderate & Moderate \\
\hline
\end{tabular}

(1957). The characteristic bruit is maximal in the vicinity of the second left interspace and is as a rule grade 2 or 3 (of 6) (Leatham and Gray, 1956). In the majority of published descriptions little or no comment has been made on the location of murmur at sites removed from the neighbourhood of the pulmonary area (Wagner and Graham, 1957; Kjellberg et al., 1959; Keith, Rowe, and Vlad, 1958; Levine and Harvey, 1959; Nadas, 1963; Wood, 1956; Braunwald, Aygen, and Ross, 1964; Fowler, 1962; Ongley et al., 1960). Indeed, poor transmission has at times been emphasized (Nadas, 1963). On the other hand, Leatham and Gray (1956) described radiation to the apex, and McKusick (1958) reported transmission to the interscapular area of the back. Until now, however, consideration has not been given to the notion that in patients with atrial septal defect systolic murmurs may occur at non-præcordial sites because of the origin of murmur in peripheral pulmonary arteries and not because of direct tissue transmission from the pulmonary orifice. The idea that murmurs can be generated by rapid flow through non-stenosed arteries is not new and has an analogy, for example, in the collateral vessel bruits of coarctation of the aorta (Spencer et al., 1958). The six atrial septal defect patients that constitute this report had widely distributed thoracic murmurs which were believed to be caused by flow in peripheral pulmonary arteries and not by transmission from the præcordium. There are a number of points relevant to the argument that such murmurs exist. (1) Although wide radiation is a recognized feature of a variety of loud cardiac bruits, the præcordial murmurs in our cases were of relatively low amplitude (grade 2 to 3 of 6 ) and hence of intensities insufficient to offer an acceptable explanation for such wide distribution on the basis of transmission alone (Fig. 1 and 2). (2) It would be reasonable to expect uniform attenuation of the peripheral murmurs if

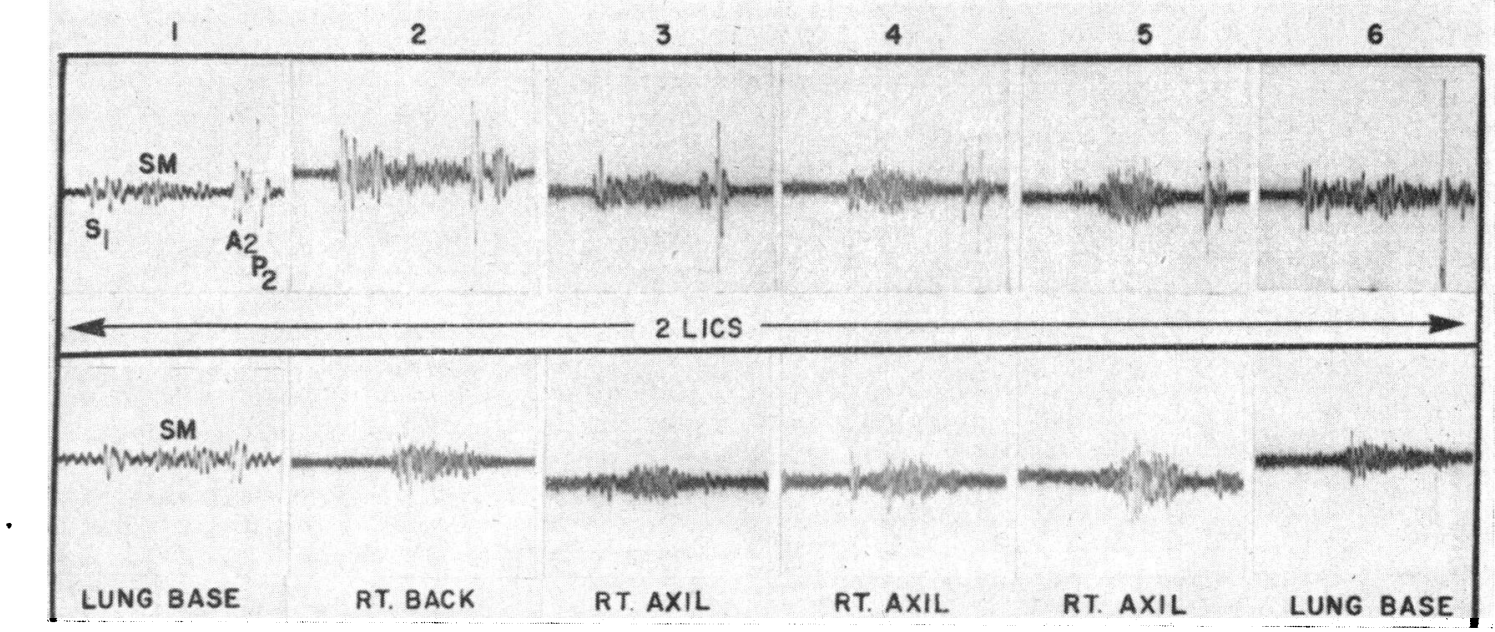

FIG. 2.-Paired phonocardiograms taken in the second left intercostal space (top row) and at one nonpræcordial site (lower row) in the patients with atrial septal defects (Cases 1-6). Note the relative intensities as well as onset of initial vibrations of the systolic murmurs at each of the two sites. 


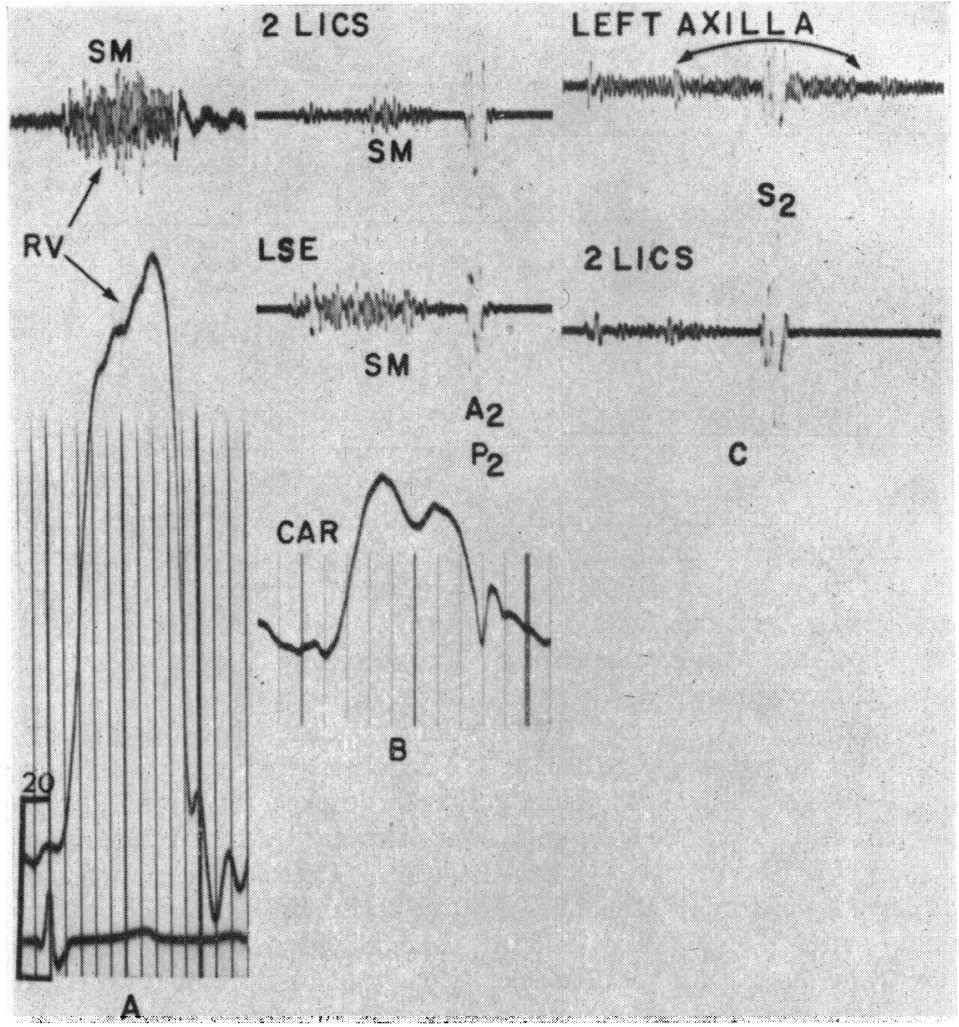

FIG. 3.-Phonocardiograms from Case 7 with ventricular septal defect. (A) Simultaneous intracardiac phonocardiogram and pressure pulse from the right ventricular cavity (RV). The intracardiac murmur is pansystolic. (B) Phonocardiograms at the second left intercostal space (ejection systolic murmur) and lower left sternal edge (ventricular septal defect murmur with marked decline in late systolic vibrations). $P_{2}$ is accentuated and synchronous with $A_{2}$. CAR-indirect carotid pulse. (C) Simultaneous phonocardiograms in the left axilla (continuous murmur, arrows) and second left intercostal space (ejection systolic murmur).

TABLE II

HEMODYNAMIC DATA

\begin{tabular}{|c|c|c|c|c|c|c|c|c|c|c|}
\hline \multirow[t]{2}{*}{ Patient } & \multicolumn{5}{|c|}{ Pressures (mm. Hg) } & \multirow{2}{*}{$\begin{array}{l}\text { Contour } \\
\text { of central } \\
\text { pulmonary } \\
\text { artery } \\
\text { pulse }\end{array}$} & \multirow{2}{*}{$\begin{array}{l}\text { Pulmonary } \\
\text { angiogram }\end{array}$} & \multirow{2}{*}{$\begin{array}{l}\text { Pulmonary/ } \\
\text { systolic } \\
\text { flow ratio }\end{array}$} & \multirow{2}{*}{$\begin{array}{l}\text { Pulmonary } \\
\text { circulation } \\
\text { time (sec.) }\end{array}$} & \multirow{2}{*}{$\begin{array}{c}\text { Opera- } \\
\text { tion }\end{array}$} \\
\hline & $\begin{array}{l}\text { Brachial } \\
\text { or femoral } \\
\text { artery }\end{array}$ & $\begin{array}{l}\text { Peripheral } \\
\text { pulmonary } \\
\text { artery }\end{array}$ & $\begin{array}{l}\text { Central } \\
\text { pulmonary } \\
\text { artery }\end{array}$ & $\begin{array}{c}\text { Right } \\
\text { ventricle }\end{array}$ & $\begin{array}{l}\text { Right } \\
\text { artery }\end{array}$ & & & & & \\
\hline 1 & $\begin{array}{l}83 / 53 \\
M 63\end{array}$ & $29 / 13$ & $\begin{array}{l}31 / 11 \\
M 20\end{array}$ & $\begin{array}{l}\text { S } 30 \\
\text { D } 12\end{array}$ & $\begin{cases}A & 14 \\
\text { V } & 12 \\
M & 13\end{cases}$ & Normal & Negative & $2 \cdot 6 / 1$ & 1.5 & Yes \\
\hline 2 & $\begin{array}{r}118 / 66 \\
M 82\end{array}$ & $40 / 20$ & $\begin{array}{l}41 / 19 \\
M \quad 27\end{array}$ & $\begin{array}{l}S 42 \\
D \quad 7\end{array}$ & $\begin{cases}\mathrm{~A} & 8 \\
\mathrm{~V} & 8 \\
\mathrm{M} & 7\end{cases}$ & Normal & Negative & $2 \cdot 5 / 1$ & 1.5 & No \\
\hline 3 & $\begin{array}{l}70 / 50 \\
\mathbf{M} 57\end{array}$ & $41 / 23$ & $\begin{array}{l}37 / 20 \\
M 26\end{array}$ & $\begin{array}{ll}S & 38 \\
D & 6\end{array}$ & $\begin{cases}\mathrm{~A} & 7 \\
\mathrm{~V} & 5 \\
\mathrm{M} & 6\end{cases}$ & Normal & & $3 / 1$ & & No \\
\hline 4 & $\begin{array}{l}81 / 48 \\
M 62\end{array}$ & $28 / 12$ & $\begin{array}{l}30 / 14 \\
M 21\end{array}$ & $\begin{array}{l}S 32 \\
D\end{array}$ & $\begin{cases}\mathrm{~A} & 8 \\
\mathrm{~V} & 8 \\
\mathrm{M} & 6\end{cases}$ & Normal & Negative & $3 \cdot 2 / 1$ & 1 & No \\
\hline 5 & $\begin{array}{l}94 / 56 \\
M 74\end{array}$ & $27 / 12$ & $\begin{array}{l}29 / 11 \\
M 18\end{array}$ & $\begin{array}{lr}S & 33 \\
\text { D } & 9\end{array}$ & $\begin{cases}\mathrm{~A} & 9 \\
\mathrm{~V} & 8 \\
\mathrm{M} & 7\end{cases}$ & Normal & Negative & $2 \cdot 7$ & 1 & No \\
\hline 6 & & Catheterize & d elsewhere & & & 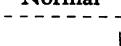 & & & & Yes \\
\hline $7 \star$ & $\begin{array}{l}85 / 60 \\
M 67\end{array}$ & $80 / 38$ & $\begin{array}{l}82 / 39 \\
M 54\end{array}$ & $\begin{array}{l}\text { S } 84 \\
\text { D } 11\end{array}$ & $\begin{cases}A & 10 \\
\mathrm{~V} & 10 \\
M & 11\end{cases}$ & Normal & Negative & $1.8 / 1$ & 2 & Yes \\
\hline
\end{tabular}

* Ventricular septal defect. 
they were caused solely by transmission from præcordial sources. In five of our patients, however, the intensities of the peripheral and præcordial murmurs were equal or nearly equal (Fig. 2), an observation in accord with McKusick's remark that the interscapular murmur associated with atrial septal defect was usually as loud in the back as anteriorly. (3) Left parasternal ejection systolic murmurs that resemble atrial septal defect bruits in both location and intensity occur with mild pulmonary stenosis (Perloff, 1964), idiopathic dilatation of the pulmonary artery (Perloff, 1964), the innocent murmur of childhood (Perloff, 1964), and with the straight back syndrome (de Leon et al., 1965), but are not transmitted to distant thoracic sites. (4) When the beginning of the murmurs in our patients could be satisfactorily timed (four instances), it was found that the onset of the peripheral vibrations tended to follow the onset of præcordial vibrations at discrete intervals (Fig. 2) which would support peripheral origin rather than direct transmission. (5) In the two patients studied before and after operation, attenuated second left interspace systolic bruits persisted after closure of the atrial septal defects, though the peripheral murmurs were wholly abolished following post-operative decline in the rate and volume of pulmonary blood flow.

The generation of peripheral pulmonary artery murmurs in patients with uncomplicated atrial septal defect is understandable in the light of the hyperkinetic pulmonary circulation that characterizes this malformation (McDonald, Emanuel, and Towers, 1959). The intensity of a murmur increases as the fourth power of the velocity of the stream (Bruns, 1959). In atrial septal defect there is not only an increase in the volume of flow through the lungs, but-more pertinent-an increase in the rate of flow through the pulmonary bed (McDonald et al., 1959). Our patients all had large shunts together with rapid pulmonary circulation times (Table II). It follows that peripheral murmurs are more likely to occur when these two hæmodynamic conditions are fulfilled and are not likely to occur in patients with small shunts and normal rates of pulmonary blood flow. Although a gracile body build might improve perception of peripheral pulmonary murmurs, our observations suggest that detection does not depend upon either age or body build.

In left-to-right shunts at either aortopulmonary or interventricular level, peripheral systolic murmurs, if present, are apt to be overshadowed by transmission of the loud præcordial bruits. Furthermore, flow rates through the lungs are judged to be less rapid than in subjects with atrial septal defects (McDonald et al., 1959). Despite these points, Case 7 appeared to be an exceptional example of a continuous peripheral pulmonary artery murmur that not only occurred in the context of ventricular septal defect but also in the presence of raised pulmonary vascular resistance and moderate left-to-right shunt (Table II, Fig. 3). Disappearance of a continuous murmur over a stenotic right pulmonary artery has been observed following operative closure of a ventricular septal defect (Franch and Gay, 1963). However, hæmodynamic and angiocardiographic data in Case 7 did not detect branch stenosis, and the murmur vanished after abolition of the shunt by operation.

The observations in this report indicate that peripheral pulmonary artery murmurs can be heard in subjects with large shunt atrial septal defects and hyperkinetic pulmonary flow. Although these murmurs may be difficult to distinguish from coexisting pulmonary branch stenosis, it is clear that they may occur in the presence of uncomplicated left-to-right shunts at atrial level. The incidence with which peripheral flow murmurs occur awaits prospective information based upon careful routine thoracic auscultation at non-præcordial sites.

\section{SUMMARY}

Left-to-right shunts at atrial level are typically associated with intracardiac systolic murmurs that originate at the pulmonary orifice. The notion that additional systolic murmurs may originate in the peripheral pulmonary arteries of subjects with uncomplicated atrial septal defects has not been hitherto entertained. The purpose of this report is to call attention to "peripheral pulmonary artery murmurs" in six patients in whom left-to-right interatrial shunts were the sole hæmodynamic faults. A number of points support the argument that such murmurs exist: (1) the præcordial bruits were of insufficient intensity to justify distributions to right chest, axillæ, and back on the basis of transmission alone; (2) in the majority of instances, transmission appeared to be an unlikely mechanism, because the peripheral murmurs occurred with little or no attenuation when compared to præcordial amplitudes; (3) systolic murmurs resembling atrial septal defect bruits, both in location and intensity, typically occurred without thoracic radiation; (4) the onset of the peripheral murmurs tended to follow the onset of the præcordial murmurs at slight but discrete intervals, a temporal sequence in accord with peripheral origin; (5) operation resulted in obliteration of the peripheral murmurs despite retention of soft præcordial bruits.

The occurrence of peripheral pulmonary artery 
murmurs in uncomplicated atrial septal defects is understandable in view of the increased velocity of pulmonary blood flow characteristic of this malformation. In subjects with left-to-right shunts at either aortopulmonary or interventricular levels, flow rates through the lungs are judged to be less rapid than flow rates with interatrial shunts, but should peripheral systolic murmurs nevertheless occur, they are apt to be overshadowed by transmission of the loud præcordial bruits.

In patients with atrial septal defects, it may be difficult to distinguish peripheral murmurs due to flow alone from those due to coexisting pulmonary branch stenosis. However, the observations herein described support the idea that peripheral pulmonary artery murmurs can occur in uncomplicated large shunt atrial septal defects with hyperkinetic pulmonary flow. In addition, the observations also serve to re-emphasize the importance of careful thoracic auscultation at non-præcordial sites.

\section{ADDENDUM}

Since the manuscript was submitted, one additional patient has been studied: a 3-year-old boy, with an isolated large shunt atrial septal defect (pulmonary to systemic flow ratio $2 \frac{1}{2}$ to 1 ), rapid pulmonary circulation time, and systolic murmurs in axillæ and back.

\section{REFERENCES}

Agustsson, M. H., Arcilla, R. A., Gasul, B. M., Bicoff, J. P., Nassif, S. I., and Lendrum, B. L. (1962). Diagnosis of bilateral stenosis of the primary pulmonary branches based on characteristic pulmonary trunk pressure curves. Circulation, 26, 421.

Arvidsson, H., Karnell, J., and Möller, T. (1955). Multiple stenosis of the pulmonary arteries associated with pulmonary hypertension, diagnosed by selective angiocardiography. Acta radiol. (Stockh.), 44, 209.

Bedford, D. E., Papp, C., and Parkinson, J. (1941). Atrial septal defect. Brit. Heart f., 3, 37.

Braunwald, E., Aygen, M. M., and Ross, J. (1964). Auscultatory and phonocardiographic findings in atrial septal defect. In The Theory and Practice of Auscultation; The Ninth Hahnemann Symposium, ed. B. L. Segal, W. Likoff, and J. H. Moyer, p. 193. F. A. Davis, Philadelphia.

Bruns, D. L. (1959). A general theory of causes of murmurs in the cardiovascular system. Amer. F. Med., 27, 360.

Campbell, M., and Deuchar, D. C. (1961). Continuous murmurs in cyanotic congenital heart disease. Brit. Heart $\mathcal{F}$., 23, 173.

D'Cruz, I. A., Agustsson, M. H., Bicoff, J. P., Weinberg, M., and Arcilla, R. A. (1964). Stenotic lesions of the pulmonary arteries. Clinical and hemodynamic findings in 84 cases. Amer. F. Cardiol., 13, 441. de Leon, A. C., Perloff, J. K., Twigg, H., and Majd, M. (1965). The straight back syndrome. Clinical cardiovascular manifestations. Circulation, 32, 193.

Fowler, N. (1962). Physical Diagnosis of Heart Disease, p. 96. Macmillan, New York.

Franch, R. H., and Gay, B. B. (1963). Congenital stenosis of the pulmonary artery branches. Amer. F. Med., 35, 512.

Grant, R. P. (1956). A precordial systolic murmur of extracardiac origin during pregnancy. Amer. Heart $\mathcal{F}$., 52, 944.

Keith, J. D., Rowe, R. D., and Vlad, P. (1958). Heart Disease in Infancy and Childhood, p. 271. Macmillan, New York.

Kjellberg, S. R., Mannheimer, E., Rudhe, U., and Jonsson, B. (1959). Diagnosis of Congenital Heart Disease, p. 419. The Yearbook Publishers, Chicago.

Leatham, A., and Gray, I. (1956). Auscultatory and phonocardiographic signs of atrial septal defect. Brit. Heart f., 18, 193.

Levine, S. A., and Harvey, W. P. (1959). Clinical Auscultation of the Heart, pp. 405, 505. W. B. Saunders, Philadelphia.

McDonald, L., Emanuel, R., and Towers, M. (1959). Aspects of pulmonary blood flow in atrial septal defect. Brit. Heart f., 21, 279.

McKusick, V. A. (1958). Cardiovascular Sound in Health and Disease, p. 346. Williams and Wilkins, Baltimore.

Moser, K. M., Houk, V. N., Jones, R. C., and Hufnagel, C. A. (1965). Chronic, massive thrombotic obstruction of the pulmonary arteries. Analysis of four operated cases. Circulation, 32, 377.

Nadas, A. S. (1963). Pediatric Cardiology, 2nd ed., p. 371. W. B. Saunders, Philadelphia.

Ongley, P. A., Sprague, H. B., Rappaport, M. B., and Nadas, A. S. (1960). Heart Sounds and Murmurs, p. 275. Grune and Stratton, New York.

Perloff, J. K. (1964). Recognition and differential diagnosis of pulmonary stenosis. In The Theory and Practice of Auscultation, ed. B. L. Segal, W. Likoff, and J. H. Moyer, p. 216. F. A. Davis, Philadelphia.

Rushmer, R. F. (1961). Cardiovascular Dynamics, 2nd ed. W. B. Saunders, Philadelphia.

Sloan, R. D., and Cooley, R. N. (1953). Congenital pulmonary arteriovenous aneurysms. Amer. F. Roentgenol., 70, 183.

Soulié, P., Laurens, P., Bouchard, F., Cornu, C., and Brial, E. (1957). Enrégistrement des pressions et des bruits intracardiaques à l'aide d'un micromanomètre. Bull. Soc. méd. Hôp. Paris, 73, 713.

Spencer, M. P., Johnston, F. R., and Meredith, J. H. (1958). The origin and interpretation of murmurs in coarctation of the aorta. Amer. Heart $\mathcal{F} ., 56,722$.

Venables, A. W. (1965). The syndrome of pulmonary stenosis complicating maternal rubella. Brit. Heart f., 27, 49.

Wagner, J., and Graham, G. R. (1957). Atrial septal defect in children. Brit. Heart f., 19, 318.

Wood, P. (1956). Diseases of the Heart and Circulation, 2nd ed., p. 361. Spottiswoode, London. 